\title{
THE CHIEF SUPREME COURT JUSTICE: A METAPHYSICAL PUZZLE?
}

\author{
DAN LÓPEZ DE SA \\ Department of Philosophy \\ New York University \\ dlds@nyu.edu
}

\begin{abstract}
SUMmARY: What are things like the Supreme Court? Gabriel Uzquiano has defended that they are groups, entities which are somehow composed of members (at certain times) but which, unlike sets (or pluralities), allow for fluctuation in membership. The main alternative holds that 'the Supreme Court' refers (at any time) to the set (or plurality) of their members (at the time). Uzquiano motivates his view by posing a metaphysical puzzle for this reductive alternative. I argue that a parallel reasoning would also find a corresponding "puzzle" in the case of singular terms like "The Chief Supreme Court Justice'.
\end{abstract}

KEY WORDS: groups, constitution, set, plurality, reference

RESUMEN: ¿Qué son cosas como el Tribunal Supremo? Gabriel Uzquiano ha defendido que son grupos, entidades de algún modo compuestas de miembros (en ciertos momentos) pero que, a diferencia de los conjuntos (o las pluralidades), permiten fluctuación en la pertenencia. La alternativa principal sostiene que 'el Tribunal Supremo' hace referencia (en cada momento) al conjunto (o pluralidad) de sus miembros (en ese momento). Uzquiano motiva su posición planteando un problema metafísico para la alternativa reduccionista. Argumento que un razonamiento paralelo también encontraría un "problema" correspondiente en el caso de términos singulares como 'el Presidente del Tribunal Supremo'.

PALABRAS CLAVE: grupos, constitución, conjunto, pluralidad, referencia

What are things like the Supreme Court, the Rochester Philharmonic Orchestra or the Boston Red Sox? In a recent paper, Gabriel Uzquiano (2004) has defended that they are groups, entities which are somehow composed of members (at certain times) but which, unlike sets (or pluralities), allow for fluctuation in membership.

The main alternative consists in claiming (roughly) that expressions like 'the Supreme Court', 'the Rochester Philharmonic Orchestra' or 'the Boston Red Sox' refer (at any time) to the set (or plurality) of their members (at the time). Uzquiano motivates his irreducibility view by posing a metaphysical puzzle for this reductive alternative. My aim in this note is to claim that parallel reasoning would also find a corresponding "puzzle" in the case of singular terms such as 'the Chief Supreme Court Justice', 'the Conductor 
of the Rochester Philharmonic Orchestra', or 'the Boston Red Sox Right Fielder'.

In section II, I rehearse Uzquiano's reasoning against the alternative view, and submit the corresponding one regarding the reference of singular terms as those mentioned. In section III, I argue that the analogy also supports Uzquiano's more precise elaborations of the puzzle. Finally, in section IV, I summarize the main result.

\section{II}

So what is the Supreme Court? One answer that suggests itself is that the Supreme Court just is the set (or plurality) of the Supreme Court Justices. What would it be otherwise? What would be this close relation that it bears to its members? As Uzquiano says, the relation is certainly an intimate one:

The members of the Supreme Court are now exactly the elements of the set of justices now serving as Supreme Court Justices. And the Supreme Court is now located wherever the elements of this set are located. It seems, in addition, that the Supreme Court holds a meeting at a time whenever the elements of (a sufficient large subset of) the set of justices serving as Supreme Court Justices hold a meeting following some official rules and procedures. And similar observations multiply. (Uzquiano 2004, p. 137)

Unfortunately, despite its attractiveness, the simple answer cannot be entirely right as it stands. The Supreme Court ruled on the matter of Roe vs. Wade twenty-one years before President Clinton appointed Stephen G. Breyer as a member in 1994. Hence the Supreme Court cannot just be a particular set or plurality that has Justice Breyer as an element, as the latter is a relation that holds eternally. The relation of the Supreme Court and particular set or pluralities should be relativized to times. ${ }^{1}$

The obvious amendment provides the main alternative reductive account that is the target of Uzquiano's puzzle. According to it, expressions like 'the Supreme Court' refer (at any time) to the set (or plurality) of their members (at the time) in much the same sense as expressions like 'the Chief Supreme Court Justice' refer (at any time) to the chief of the Supreme Court Justice (at the time). ${ }^{2}$

\footnotetext{
${ }^{1}$ President Clinton could have appointed someone else in 1994. All observations about times reproduce as observations about worlds.

${ }^{2}$ Notice that the defender of the alternative reductive account need not take a view about what kind of expressions 'the Supreme Court' and 'the Chief Supreme
} 
But, according to Uzquiano, the view faces a metaphysical puzzle:

Suppose that the United States Senate appoints all Supreme Court Justices to a Special Committee on Judicial Ethics at a certain time. And suppose no one else is ever in that committee. Thus there is at least a time at which the set of individuals then serving as members of the Special Committee on Judicial Ethics is identical with the set of individuals then serving as Supreme Court Justices. [...] [Under the alternative reductive view, there is] just one set which is both the Supreme Court at $t$ and the Special Committee of Judicial Ethics at $t$.

This should strike us as an unacceptable conclusion. The Special Committee on Judicial Ethics and the Supreme Court are in session at different times and under different official rules and procedures. They enjoy different powers, and they may, in fact, act differently. Sometimes, their actions may even enter into conflict. (Uzquiano 2004, pp. 141-142)

I claim that if this is a puzzle, there would be corresponding ones with respect to the other singular cases considered above. For suppose that the members of the Special Committee on Judicial Ethics elect the Chief Supreme Court Justice as the Head of the Special Committee on Judicial Ethics. As I have just alluded, one popular view, suggested also by Uzquiano (2004, p. 138), has it that expressions like 'the Chief Supreme Court Justice' or 'the Head of the Special Committee on Judicial Ethics' refer (at any time) to the person who holds a certain position (at the time). This familiar view would also suffer from a similar metaphysical "puzzle". For it entails that there is one person who is both the Chief Supreme Court Justice at a given time and the Head of the Special Committee on Judicial Ethics at that very same time. And it is also quite obviously the case that the Chief Supreme Court Justice and the Head of the Special Committee on Judicial Ethics chair different sessions at different times and under different official rules and procedures. They enjoy different powers, and they may, in fact, act differently. Sometimes, their actions may even enter into conflict.

It looks as if we have as much reason to argue against the target view and hence in favor of the view that the Supreme Court and the Special Committee on Judicial Ethics are groups, as we do to argue against the familiar view mentioned and hence in favor of the view

Court Justice' both are, either peculiar names or peculiar descriptions. It will suffice that the relation between expressions and entities (at times) I am referring to by 'refer' is the same one in both. 
that the Chief Supreme Court Justice and the Head of the Special Committee on Judicial Ethics are not real but "office" people, in Sidelle 1992's phrase, somehow composed of different people holding the different positions at the different times. Office people are less tied to their "holders", as it were, and allow for fluctuations.

Now it is crucial to appreciate that it would simply beg the question at stake just to claim that expressions like "the Supreme Court' are genuinely referring expressions whereas expressions like 'the Chief Supreme Court Justice' are by contrast definite descriptions. The main contention of the alternative reductive view has been precisely that expressions like 'the Supreme Court' refer (at any time) to the set (or plurality) of their members (at the time) in much the same sense as expressions like 'the Chief Supreme Court Justice' refer (at any time) to the chief of the Supreme Court Justice (at the time), being neutral as to whether both kind of expressions are (peculiar) names or (peculiar) descriptions. ${ }^{3}$ The metaphysical puzzle by itself fails to provide an argument against such a contention. I now argue that Uzquiano's more precise objections (2004, pp. 142-145) are also only as persuasive as the corresponding ones regarding the other singular cases.

Uzquiano offers three more elaborate objections against the alternative reductive account concerning 'the Supreme Court'. I consider them in turn and argue that they would challenge the familiar view about 'the Chief Supreme Court Justice' with as much success.

Assume $t$ is a time at which the set of individuals serving as Supreme Court Justices is identical with the set of individuals serving on the Special Committee on Judicial Ethics. And suppose that there is a session of the Supreme Court at $t[\ldots] .{ }^{4}$ No meeting of the Special Committee on Judicial Ethics has been scheduled or called for that time. The problem is that while (1) would seem to be true in that circumstance, (2) is hopelessly false:

(1) The Supreme Court is in session at $t$.

(2) The Special Committee on Judicial Ethics is in session at $t$.

\footnotetext{
${ }^{3}$ See note 2 above.

${ }^{4}$ The deleted portion reads "but no session of the Special Committee on Judicial Ethics takes place at $t^{\prime \prime}$ (Uzquiano 2004, p. 142). This is what is at stake.
} 
But this seems incompatible with the claim that the Supreme Court as of $t$ is identical with the Special Committee on Judicial Ethics as of $t$. (Uzquiano 2004, p. 142) (U) $^{5}$

Although (2) is certainly defective in the envisaged situation, I think it is at most debatable that the defectiveness in place consists in literal falsehood, rather than calling for some sort of pragmatic account. Be this as it may, the pair (1) and (2) do not differ, from the pair below:

$\left(1^{*}\right)$ The Chief Supreme Court Justice chairs the session at $t$.

$\left(2^{*}\right)$ The Head of the Special Committee on Judicial Ethics chairs the session at $t$.

Uzquiano considers, on behalf of his opponent, a response consisting in maintaining that the (let us assume) difference in truth-value between (1) and (2) is compatible with the identity claim, provided that the attributed properties are, respectively, of the sort of being in session as the Supreme Court at a time and being in session as the Special Committee on Judicial Ethics at a time. However, he finds the suggestion to be at fault:

What I think is problematic is the fact that we still seem, on the view under consideration, to be forced to acknowledge the truth of:

(3) The Special Committee on Judicial Ethics is in session as the Supreme Court at $t$.

And this surely seems unacceptable. Whatever powers the Special Committee on Judicial Ethics otherwise enjoys, being in session as the Supreme Court is not one of them - not even when its members happen to be exactly those individuals serving as Supreme Court Justices at the time. (Uzquiano 2004, p. 143)

To my ears, talk about "as..." sometimes evokes a reading in which (3) is acceptable. But surely it also has other readings. With respect to them, it seems to me to be again at most debatable to claim that the relevant unacceptability is incompatible with literal truth. But in any case, the situation is intuitively similar with respect to:

$\left(3^{*}\right)$ The Head of the Special Committee on Judicial Ethics chairs the session as the Chief Supreme Court Justice at $t$.

\footnotetext{
${ }^{5} \mathrm{I}$ have altered the numbering in this and subsequent quotes.
} 
Finally, Uzquiano rightly observes "relativizations" of the envisaged sort seem inappropriate in "extensional" contexts as that of is one of. But then, he claims,

It seems difficult to block the inference:

(4) The Special Committee on Judicial Ethics is one of the committees assembled by the Senate.

(5) The Special Committee on Judicial Ethics is identical with the Supreme Court.

Therefore,

(6) The Supreme Court is one of the committees assembled by the Senate.

But (6) is surely false, as it is plain that the Senate did never assembled the Supreme Court. If we follow the argument where it leads, given the truth of:

(7) None of the committees assembled by the Senate enjoys the power to interpret the constitution,

we seem able to conclude:

(8) The Supreme Court does not enjoy the power to interpret the constitution, which is again, plainly false. (Uzquiano 2004, p. 144)

Quite unsurprisingly at this stage, I find more than one claim here at best optional, and submit the following whose intuitive similarity is, in my view, striking:

$\left(4^{*}\right)$ The Head of the Special Committee on Judicial Ethics was elected by the members of the Special Committee on Judicial Ethics.

(5*) The Head of the Special Committee on Judicial Ethics is identical with the Chief Supreme Court Justice.

Therefore,

(6*) The Chief Supreme Court Justice was elected by the members of the Special Committee on Judicial Ethics. 
And:

$\left(7^{*}\right)$ None of those elected by the members of the Special Committee on Judicial Ethics presides when the Senate tries impeachments of the President of the United States.

Therefore,

(8*) The Chief Supreme Court Justice does not preside when the Senate tries impeachments of the President of the United States. ${ }^{6}$

I take it that intuitions against $\left(6^{*}\right)$ are as strong as those against (6), and intuitions in favor of $\left(7^{*}\right)$ are as strong as those in favor of (7). Thus, given the uncontroversial truth of $\left(4^{*}\right)$ and (4) and the uncontroversial falsity of $\left(8^{*}\right)$ and (8), Uzquiano's case against a reductive account which entails (5) is as strong as a case against a proposal which entails $\left(5^{*}\right)$.

I conclude that Uzquiano's defence of the view that the Supreme Court and the Special Committee on Judicial Ethics are groups would, if successful, also establish that the Chief Supreme Court Justice and the Head of the Special Committee on Judicial Ethics are not real but "office" people. Thus, if any strategy is successful to the effect that expressions like 'the Chief Supreme Court Justice' refers (at any time), even in the problematic cases, to the person holding a certain position (at the time), there will be corresponding strategies also effective in supporting the alternative reductive view of expressions like 'the Supreme Court' referring (at any time) to the set (or plurality) of their members (at the time). As I have suggested, I suspect that there will be such strategies, in both cases. But the context of this brief note is not appropriate for trying to provide a positive account as to substantiate this suspicion of mine. ${ }^{7}$

${ }^{6}$ Uzquiano also offers a different kind of consideration against the alternative reductive view: there is certainly a sense in which "we can conceive of a situation in which the Special Committee on Judicial Ethics, but not the Supreme Court, joins a Committee of Ethics Committees" (Uzquiano 2004, pp. 145-146). But again, the situation is intuitively similar with respect to the other singular cases. In the same sense there might well be commissions composed by the Head of the Special Committee on Judicial Ethics but not by the Chief Supreme Court Justice.

${ }^{7}$ Thanks to Gabriel Uzquiano for very helpful and stimulating discussion, as well as to the St Andrews Metaphysics Group, especially to Robbie Williams, and 


\section{REFERENCES}

Sidelle, A., 1992, "Rigidity, Ontology and Semantic Structure", Journal of Philosophy, vol. 89, pp. 410-430.

Uzquiano, G., 2004, "The Supreme Court and the Supreme Court Justices: A Metaphysical Puzzle", Noûs, vol. 38, pp. 135-153.

Received: December 7, 2005; revised: June 22, 2006; accepted: February 7, 2007.

to anonymous referees for their comments and suggestions. Thanks also to the MEC EX2004-1159 and HUM2004-05609-C02-01 for financial support, and to Mike Maudsley for his linguistic revision.

Crítica, vol. 39, no. 115 (abril 2007) 